\title{
Treatment of aortic arch aneurysms: Open surgery or hybrid procedure?
}

\author{
Arkus aort anevrizmalarının tedavisi: Açık cerrahi mi hibrid işlem mi?

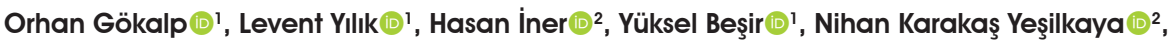 \\ Kazım Ergüneş (i) ${ }^{2}$, Banu Lafcı $\mathbb{1}^{2}$, Ali Gürbüz ${ }^{1}$ \\ Institution where the research was done: \\ Medicine Faculty of Katip Çelebi University, İzmir, Turkey \\ Author Affiliations: \\ 'Department of Cardiovascular Surgery, Medicine Faculty of Katip Çelebi University, İzmir, Turkey \\ ²Department of Cardiovascular Surgery, Katip Çelebi University, Atatürk Training and Research Hospital, İzmir, Turkey
}

\begin{abstract}
Background: This study aims to compare the results of hybrid procedure and open surgery for the treatment of aortic arch aneurysms.

Methods: Twenty-six patients (21 males, 5 females; mean age $56.6 \pm 12.4$ years; range, 20 to 83 years) who underwent total aortic arch replacement for aortic arch aneurysm between January 2004 and January 2010 were retrospectively analyzed. The patients were divided into two groups: open conventional surgery group (group 1, $\mathrm{n}=15$ ) and hybrid procedure (total debranching of the aortic arch and simultaneous endovascular stent) group (group 2, $\mathrm{n}=11$ ). Survival rates and need for reoperation were compared between the groups.

Results: The hybrid procedure was found to be more favorable in terms of postoperative revision, extubation period, and drainage amounts. However, there was no statistically significant difference in the survival rates, need for reoperation, and major adverse cardiovascular events between the groups.

Conclusion: Our study results suggest that conventional open surgery and hybrid procedure are similar in terms of survival and short-to-mid-term results in patients undergoing total aortic arch replacement for aortic arch aneurysm.
\end{abstract}

Keywords: Aortic arcus aneurysm; conventional open surgery; hybrid procedure.

The conventional method for the treatment of aortic arch aneurysms is open surgery via graft interposition. ${ }^{[1]}$ Although this method is commonly practiced, it is still associated with high surgical morbidity and mortality,
$\ddot{O} Z$

Amaç: Bu çalışmada arkus aort anevrizmalarının tedavisinde hibrid işlem ve açık cerrahi sonuçları karşılaştırıldı.

Çalışma planı: Ocak 2004 - Ocak 2010 tarihleri arasında arkus aort anevrizması nedeniyle total arkus aort replasmanı yapılan 26 hasta (21 erkek, 5 kadın; ort. yaş $56.6 \pm 12.4$ yıl; dağılım, 20-83 yıl) retrospektif olarak değerlendirildi. Hastalar açık konvansiyonel cerrahi grubu (grup 1, n=15) ve hibrid işlem (aynı seansta total arkus aort debranching ve endovasküler stent implantasyonu) grubu (grup 2, n=11) olarak iki gruba ayrıldı. Sağkalım oranları ve tekrar ameliyat gereksinimi gruplar arasında karşılaştırıldı.

Bulgular: Ameliyat sonrası revizyon, ekstübasyon süresi ve drenaj miktarları açısından hibrid işlem daha iyi bulundu. Ancak sağkalım oranları, tekrar ameliyat gereksinimi ve ciddi advers kardiyovasküler olaylar açısından gruplar arasında istatistiksel olarak anlamlı bir fark yoktu.

Sonuç: Çalışma sonuçlarımız arkus aort anevrizması nedeniyle total arkus aort replasmanı yapılan hastalarda sağkalım ve kısa ila orta dönem sonuçlar açısından açık konvansiyonel cerrahi ve hibrid işlemin benzer olduğunu göstermektedir.

Anahtar sözcükler: Arkus aort anevrizması; konvansiyonel açık cerrahi; hibrid işlem.

particularly in the patients with several comorbidities. ${ }^{[1-8]}$ New technologies have been developed to address these problems of open surgery, and surgeons currently tend to prefer alternative and less invasive treatment options. ${ }^{[1,2,6,8]}$

Received: October 04, 2017 Accepted: March 27, 2018

Correspondence: Orhan Gökalp, MD. Katip Çelebi Üniversitesi Tıp Fakültesi, Kalp ve Damar Cerrahisi Anabilim Dalı, 35620 Çiğli, İzmir, Turkey. Tel: +90 232 - 2444444 e-mail: gokalporhan@yahoo.com

Cite this article as:

Gökalp O, Yilık L, İner H, Beșir Y, Karakaș Yeșilkaya N, Ergüneș K, et al. Treatment of aortic arch aneurysms: Open surgery or hybrid procedure? Turk Gogus Kalp Dama 2018:26(3):351-358. 
Currently, one of the leading alternatives is hybrid procedure, including the use of both open surgery and endovascular methods simultaneously. Despite being a less invasive treatment option for many aortic lesions, endovascular repair may not be possible in every case, mainly due to the necessity to obstruct orifices of one or more aortic arch branches to provide an adequate proximal or distal fixation site. This is because it may be necessary to close one or more aortic arch vessel orifices and the aneurysm and adequate proximal or distal fixation of the endograft can be ostracized. Consequently, there is a need for hybrid treatments for thoracic aortic aneurysm, involving of the aortic arch.

In the present study, we aimed to compare the results of open surgery and hybrid procedure in patients with aortic arch aneurysms.

\section{PATIENTS AND METHODS}

A total of 26 patients (21 males, 5 females; mean age $56.6 \pm 12.4$ years; range, 20 to 83 years) who underwent surgery for aortic arch aneurysm between January 2004 and January 2010 were included in this study. Patients with acute aortic dissections were excluded. The study ptotocol was approved by the İzmir Katip Celebi University local ethics committee. The study was conducted in accordance with the principles of the Declaration Helsinki.

Postoperative follow-up data of the patients were taken from the hospital archive department and retrospectively analyzed using clinical variables. All patients underwent contrast-enhanced thoracoabdominal computed tomography (CT), echocardiography, and coronary angiography before operation. In addition, all patients underwent a comprehensive color Doppler ultrasonography, if elements of the supracoronary arch were involved.

The patients who underwent total aortic arch replacement using conventional open surgery were assigned to group $1(n=15)$, while those who underwent total aortic arch debranching and endovascular stent implantation were assigned to group $2(n=11)$. Both groups were compared on the basis of pre, intra-, and postoperative data and short-term and mid-term results were evaluated.

As described by Boehme et al., ${ }^{[9]}$ the diagnosis of systemic inflammatory response syndrome (SIRS) was made during the postoperative period. According to these criteria, at least two of the followings were required: body temperature $>38.0^{\circ} \mathrm{C}$ or $<36.0^{\circ} \mathrm{C}$, heart rate $>90 / \mathrm{min}$, respiratory rate $>20 / \mathrm{min}$, and leucocyte count $>12,000 / \mu \mathrm{L}$ or $<4,000 / \mu \mathrm{L}$.

\section{Conventional open surgical procedure}

The operations were performed under general anesthesia. First, arterial cannulation was performed in all patients with an $8 \mathrm{~mm}$ Dacron graft attached to the right subclavian artery for anterograde cerebral perfusion (ACP). Following median sternotomy, right atrial venous cannulation was performed, followed by antegrade and continuous retrograde isothermic hyperpotassemic blood cardioplegia for myocardial protection. Nylon tapes were passed around the branches of aortic arch. Following cross-clamping, the patients were cooled down to 24 to $26^{\circ} \mathrm{C}$. Body circulatory arrest was achieved. The cerebral circulation was provided with ACP. All branches of the aortic arch were clamped during ACP. The pump flow was adjusted to maintain a right radial arterial pressure of 50 to $60 \mathrm{mmHg}$. First, a Dacron graft of suitable diameter was anastomosed to the descending aorta. Next, the cross-clamp was placed on the main graft, rewarming was started, and the main graft was anastomosed to the ascending aorta. The cross-clamp was removed and the branches of the aortic arch were anastomosed to the main graft.

\section{Surgical procedure of hybrid intervention}

In patients with an isolated aortic arch aneurysm, after median sternotomy and heparinization, the proximal end of a $14 \mathrm{~mm}$ Dacron graft was anastomosed to the proximal ascending aorta in an end-to-side fashion using a side-clamp without using cardiopulmonary bypass (CPB). The distal end of the graft was anastomosed to the brachiocephalic artery in an end-to-end fashion. The proximal end of a second $10 \mathrm{~mm}$ Dacron graft, which would be used for the deployment of antegrade endovascular graft, was anastomosed to the $14 \mathrm{~mm}$ Dacron graft in an endto-side fashion. Other two $8 \mathrm{~mm}$ Dacron grafts were anastomosed to the $14 \mathrm{~mm}$ graft and the distal ends of these two grafts were anastomosed to the left carotid artery and left subclavian artery in an end-to-end fashion. A marker was positioned on the proximal anastomosis site of $14 \mathrm{~mm}$ Dacron graft to evaluate the level of the endograft.

For patients with an ascending aortic aneurysm in addition to an aortic arch aneurysm, CBP is a must for the replacement of ascending aorta. ${ }^{[1,2]}$ Proximal anastomosis of the ascending aortic graft was performed using conventional technique after crossclamping (aortic root replacement with composite graft can be considered for patients with aortic valve regurgitation, but aortic valve was normal in our patients). Distal attachment site was either distal 
ascending aorta or proximal aortic arch. Positioning distal anatomosis of the graft to the aneurysmatic section seemed to cause postoperative problems, although these risks were excluded by positioning the proximal attachment site of the endograft on proximal level of distal anastomosis of the Dacron graft. After distal anastomosis, cross-clamping time was ended and arcus branch anastomosis was done under sideclamping. In this part, proximal end of $14 \mathrm{~mm}$ Dacron graft was anastomosed to the ascending aortic graft, but not to native ascending aorta as done for isolated aortic arch replacement.

\section{Endovascular procedure of hybrid intervention}

After surgical debranching, an antegrade endovascular graft was placed via the $10 \mathrm{~mm}$ Dacron graft previously anastomosed to the main root graft. Zone 0 was used in all patients. Proximal and distal landing zones of endograft were at least $2 \mathrm{~cm}$ in length. Control angiography was performed in hybrid operating room to check endoleaks, graft patency, and graft configuration. An iliac extender limb was placed in a patient with type 1B endoleak. Operation was terminated after control angiography. The hybrid procedure technique was previously described by Yilik et al. ${ }^{[1]}$

\section{Statistical analysis}

Statistical analysis was performed using IBM SPSS version 22.0 (IBM Corp., Armonk, NY, USA). Descriptive data were expressed in mean, standard deviation, median lowest, highest, frequency and ratio values. The Fisher's exact test was used for intragroup comparisons of the categorical data, while the Mann-Whitney U test was used for the intragroup comparisons of the continuous variables. Survival analysis was performed using the Kaplan-Meier plot and log-rank test. A $p$ value of $<0.05$ was considered statistically significant.

\section{RESULTS}

In terms of preoperative variables, the only difference was the rate of previous operations. The rate of previous operations was significantly higher in group 2 than group $1(\mathrm{p}<0.05)$ (Table 1). In terms of the perioperative data, there was a significantly higher rate of ascending aortic replacement in group 1 than group $2(\mathrm{p}<0.05)$ (Table 2). Ascending aortic replacement was performed in all patients undergoing open surgery with aortic root replacement in four patients. Of these patients, two underwent a previous cardiovascular operation (aortic valve replacement and femoropopliteal bypass, respectively).

Table 1. Preoperative data

\begin{tabular}{|c|c|c|c|c|c|c|c|}
\hline & \multicolumn{3}{|c|}{ Group $1(\mathrm{n}=15)$} & \multicolumn{3}{|c|}{ Group $2(\mathrm{n}=11)$} & \multirow[b]{2}{*}{$p$} \\
\hline & $\mathrm{n}$ & $\%$ & Mean \pm SD & $\mathrm{n}$ & $\%$ & Mean \pm SD & \\
\hline Age (year) & & & $55.4 \pm 13.9$ & & & $65.4 \pm 6.2$ & 0.054 \\
\hline \multicolumn{8}{|l|}{ Gender } \\
\hline Female & 3 & 20 & & 2 & 18.2 & & 1.000 \\
\hline Hypertension & 9 & 60 & & 10 & 90.9 & & 0.178 \\
\hline Chronic obstructive pulmonary disease & 5 & 33.3 & & 6 & 54.5 & & 0.426 \\
\hline Diabetes mellitus & 4 & 26.7 & & 5 & 45.5 & & 0.419 \\
\hline Peripheral arterial disease & 2 & 13.3 & & 1 & 9.1 & & 1.000 \\
\hline Chronic renal failure & 1 & 6.7 & & 2 & 18.2 & & 0.556 \\
\hline Smoking & 11 & 73.3 & & 8 & 72.7 & & 1.000 \\
\hline Previous surgery & 2 & 13.3 & & & & & 0.038 \\
\hline Coronary artery bypass + AVR & 1 & 6 & & & & & \\
\hline Femoropopliteal bypass & 1 & 6 & & & & & \\
\hline Supracoronary aortic replacement & & & & 4 & 36.3 & & \\
\hline Coronary artery bypass & & & & 1 & 9 & & \\
\hline TEVAR & & & & 1 & 9 & & \\
\hline Preoperative ejection fraction & & & $52.3 \pm 6.8$ & & & $56.4 \pm 8.1$ & 0.132 \\
\hline Body Mass Index & & & $24.9 \pm 3.4$ & & & $32.3 \pm 9.4$ & 0.052 \\
\hline EuroSCORE & & & $7.2 \pm 2.3$ & & & $7.4 \pm 2.1$ & 0.560 \\
\hline Aneurysm diameter (mm) & & & $65.5 \pm 11.7$ & & & $67.5 \pm 6.9$ & 0.621 \\
\hline
\end{tabular}

SD: Standard deviation; AVR: Aortic valve replacement; TEVAR: Thoracic endovascular aortic replacement; EuroSCORE: European System for Cardiac Operative Risk Evaluation. 


\begin{tabular}{|c|c|c|c|c|c|c|c|}
\hline & \multicolumn{3}{|c|}{ Group $1(n=15)$} & \multicolumn{3}{|c|}{ Group $2(n=11)$} & \multirow[b]{2}{*}{$p$} \\
\hline & $\mathrm{n}$ & $\%$ & Mean \pm SD & $\mathrm{n}$ & $\%$ & Mean \pm SD & \\
\hline Emergency surgery & 2 & 13.3 & & 0 & & & 0.492 \\
\hline Concomitant procedures-ascending aortic replacement & 15 & 100 & & 3 & 27.3 & & 0.000 \\
\hline Concomitant procedures-aortic root replacement & 4 & 26.7 & & 0 & & & 0.113 \\
\hline Other concomitant procedures & 4 & 26.7 & & 0 & & & 0.113 \\
\hline Aortic valve replacement & 2 & 13.3 & & 0 & & & \\
\hline Coronary artery bypass & 2 & 13.3 & & 0 & & & \\
\hline Duration of operation (min) & & & $337.3 \pm 77.2$ & & & $360.2 \pm 95.5$ & 0.517 \\
\hline
\end{tabular}

SD: Standard deviation.

Eight of the patients in the hybrid group had an isolated aortic arch aneurysm, two had a concomitant ascending aortic aneurysm and aortic arch aneurysm, and one had an ascending aortic aneurysm with an aortic arch aneurysm and descending aortic aneurysm (i.e., mega aorta syndrome). In the same group, six patients underwent a previous cardiac operation (supracoronary aortic replacement due to type 1 aortic dissection in four patients -none of them had false lumen resistance-, a coronary bypass in one, and thoracic endovascular aortic replacement [TEVAR] due to a descending aortic aneurysm in one).
One patient with an isolated aortic arch aneurysm also had prostate cancer and an abdominal aortic aneurysm. This patient underwent simultaneous aortic arch debranching and endovascular aortic replacement (EVAR). However, the operative data in this study were not assessed statistically as the amount of data was limited (e.g., data from the CPB and cross-clamping periods in the hybrid events with $\mathrm{CPB}$, as well as the open surgery group).

The median interval of $\mathrm{CPB}$ in group 1 was 112 (range, 78 to 105) min, and that of cross-clamping

Table 3. Postoperative data

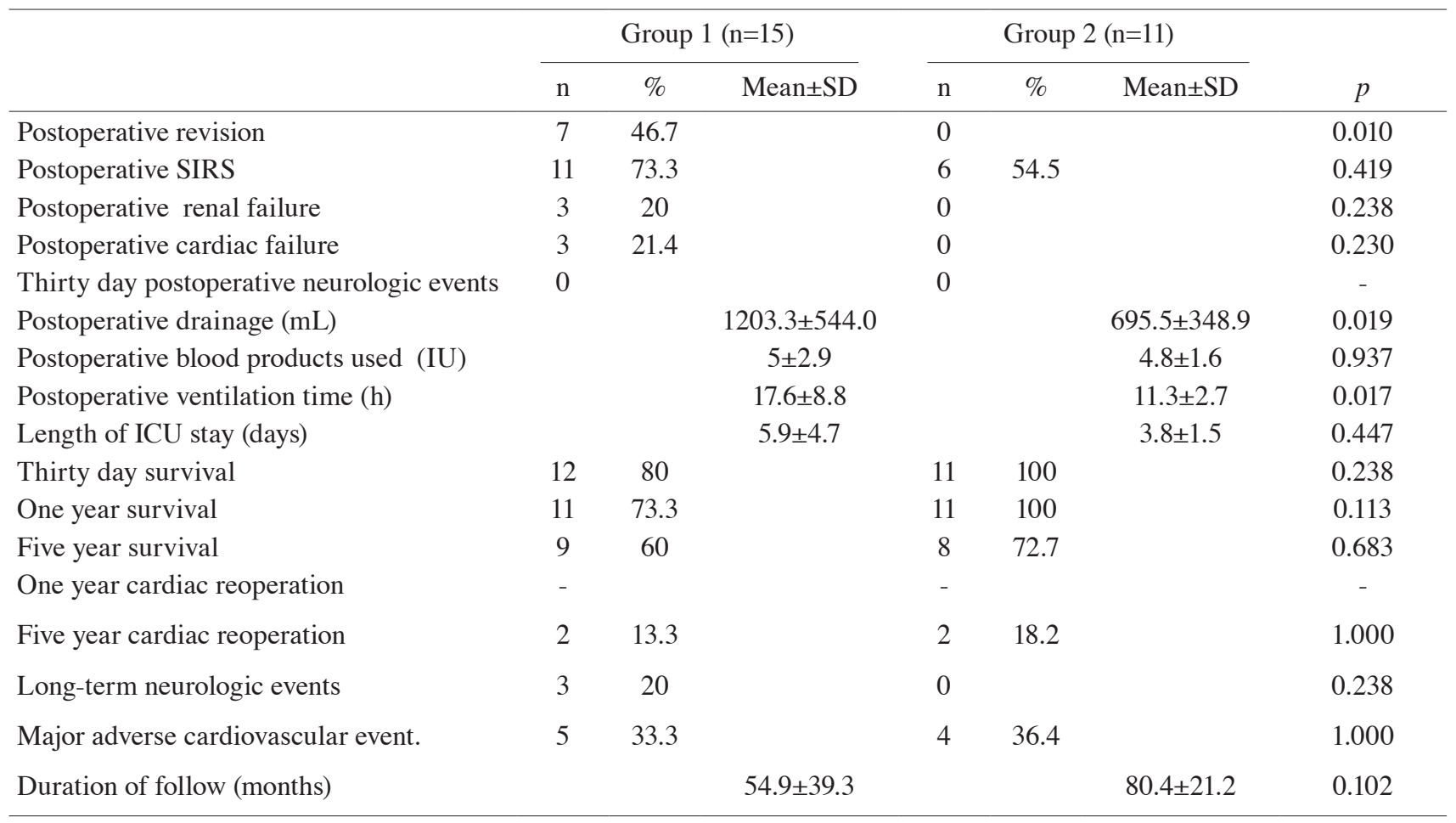

SD: Standard deviation; SIRS: Systemic inflammatory response syndrome; ICU: Intensive care unit. 
was 60 (range, 38 to 138 ) min. In three patients who underwent $\mathrm{CPB}$ in group 2, the median $\mathrm{CPB}$ interval was 60 (range, 45 to 170) $\mathrm{min}$, while the median cross-clamp interval was 37 (range, 28 to 110) min. In addition, the mean diameter of the endografts used in the hybrid group was $43 \pm 2$ (range, 40 to 45 ) $\mathrm{cm}$, and their mean length was $18.6 \pm 3.2$ (range, 15 to 25 ) $\mathrm{cm}$. The control angiographies of the patients who underwent hybrid surgery revealed type $1 \mathrm{~B}$ endoleak in one patient $(9 \%)$.

No statistically significant difference was found between the groups in terms of the postoperative variables including SIRS, chronic renal failure, heart failure, rate of neurological events, blood transfusion, duration of intensive care unit (ICU) stay, and 30-day survival $(p>0.05)$. However, postoperative revision was significantly higher, the extubation period was significantly longer, and the amount of drainage was significantly higher in group 1, compared to group 2 $(\mathrm{p}<0.05)$ (Table 3). In group 1 , three patients died from low cardiac output in the early postoperative period, while no deaths occurred in the early postoperative period in group 2.

Comparison of the groups in terms of longterm follow-up revealed that the rates of oneyear survival, five-year survival, freedom from reoperation for one year, freedom from reoperation for five years, long-term neurological events, and major adverse cardiovascular events (MACEs) were similar (Figure 1). In the open surgery group, one patient died in the postoperative ninth month due to hemorrhagic infarcts, one patient died in the postoperative $26^{\text {th }}$ month due to an intracerebral hematoma which developed in the ICU following surgery of a proximal pseudoaneurysm, and one patient died in the postoperative $42^{\text {nd }}$ month due to multiple organ dysfunction. In the hybrid group, no patient died during the first postoperative year; (a)

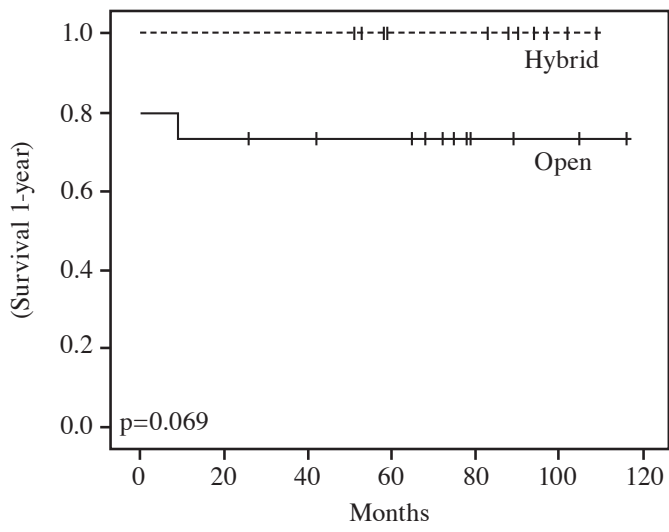

(c)

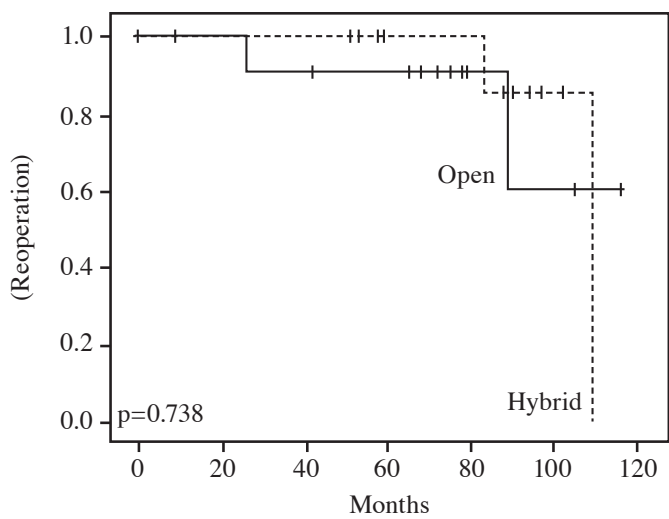

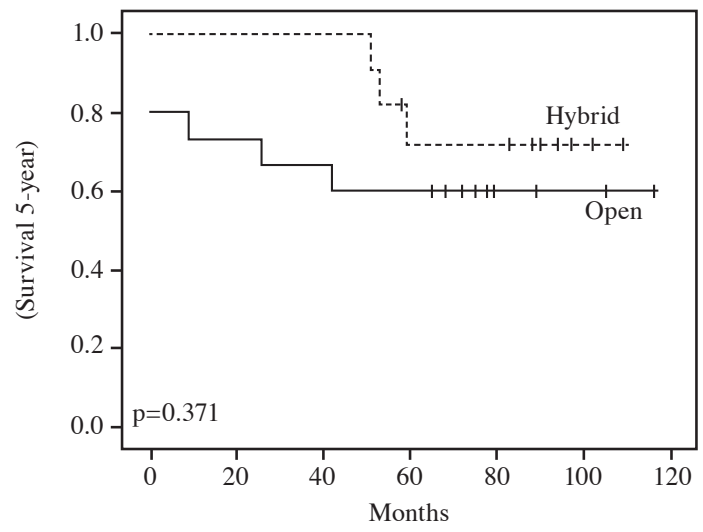

(d)

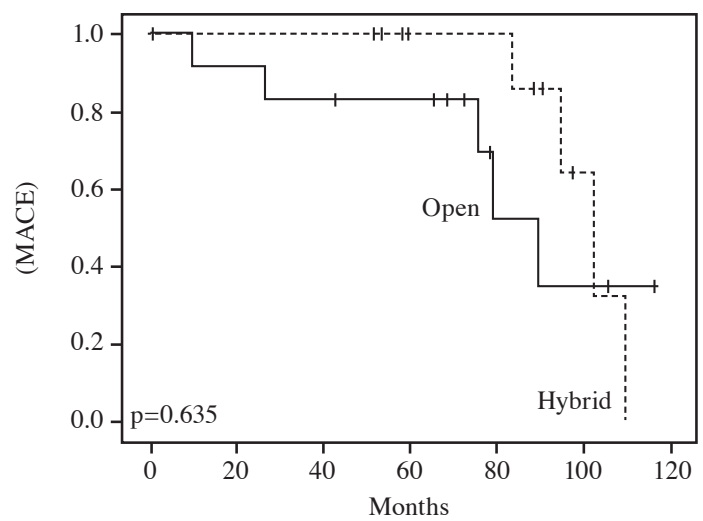

Figure 1. Kaplan-Meier Curve (a) One-year survival, (b) five-year survival, (c) five-year freedom from cardiac reoperation, (d) Freedom from MACE (Major Adverse Cardiovascular Event). 
however, two patients died in the postoperative $51^{\text {st }}$ and $59^{\text {th }}$ months, respectively, due to multiple organ dysfunction. In the postoperative $53^{\text {rd }}$ month, one patient who underwent a re-EVAR procedure to treat an aortoenteric fistula died from major bleeding. In both groups, there was no need for re-cardiac surgery during the first postoperative year. In the open surgery group, two patients required reoperation. In the first patient, supracoronary ascending aortic replacement and total aortic arch replacement were performed due to a pseudoaneurysm arising from the proximal anastomosis in the postoperative $26^{\text {th }}$ month. The second patient was reoperated in the postoperative $89^{\text {th }}$ month due to aortic valve failure (the aortic root was not treated during the first operation). In the hybrid group, due to an aneurysmal development in the proximal attachment site in the postoperative $62^{\text {nd }}$ month, re-TEVAR was required in one patient (the ascending aorta was not treated during the first operation). Reoperation was also necessary in another patient due to aortic valve failure caused by an aneurysm in the proximal adherence zone in the postoperative $75^{\text {th }}$ month. In the hybrid group, EVAR was performed in one patient in whom an abdominal aortic aneurysm developed during long-term follow-up. One patient developed a temporary ischemic attack and, with the exception of the two patients who died in the surgery group, none of the patients developed a neurological event in the hybrid group.

The mean follow-up was $54.9 \pm 39.3$ months in group 1 and $80.4 \pm 21.6$ months in group 2, indicating a shorter follow-up period for group 1 . The follow-up period for three patients who were lost to follow-up within the first 30 days was calculated as 0 .

\section{DISCUSSION}

Technical and clinical challenges rising from the anatomical structures of aneurysms of the aortic arch have led to alternative treatment options to conventional open surgery. ${ }^{[1,10-15]}$ Of these options, the leading choice is endovascular intervention, which is used more commonly currently, thanks to the advances in technology and increasing experience. However, as the proximal attachment site of the endovascular grafts coincide with the aortic arch or more proximal areas, one or more aortic arch branches may be covered by the endovascular graft. To overcome this problem, hybrid procedure has been developed that includes surgical reconstruction of aortic arch elements and endovascular repair of aneurysms. ${ }^{[1]}$ As it is used more commonly today, the results of these hybrid procedures have started to appear in publications. To the best of our knowledge, there are a few studies comparing open surgery with the hybrid technique in the literature. ${ }^{[12-18]}$ Yet, examination of these limited studies revealed no homogeneity among patient groups. Most of the studies included patients with aortic dissections. ${ }^{[12-15]}$ Furthermore, some studies compared open surgery and hybrid procedures and showed that the rates of dissection etiology between the groups were different. ${ }^{[12,17]}$ In such studies, dissection patients must be removed from studies or the groups should be equalized in this respect. Outcome results of the dissection patients are worse and this situation may affect the study results. Another problem related to homogeneity among patient groups in these studies is that EuroSCORE (European System for Cardiac Operative Risk Evaluation) values are higher in the hybrid groups due to the abundant comorbidity factors and age..$^{[12,14-17]}$ Notably, the hybrid procedure is used in higher-risk patients, as it is less invasive than open surgery. However, this may result in loss of homogeneity between the patients undergoing the two techniques, which may affect the results. Unlike previous studies, in our study, we only included patients with aneurysms and excluded those with dissections. Moreover, both groups consisted of similar patients in terms of all other variables, including EuroSCOREs and excluded those who underwent a previous operation. Of note, it should be kept in mind that the number of prior operations is higher in hybrid procedure group.

The hybrid procedure for the treatment of aortic arch aneurysms is considered less invasive than open surgery with a shorter stay in the ICU, a shorter extubation period, and less bleeding. ${ }^{[14]}$ Recently, there have been studies with preoperative data that support this opinion, reporting that there is no difference between these two methods. Iba et al. ${ }^{[16]}$ found that the length of stay in both the ICU and the hospital were shorter in patients who underwent a hybrid procedure than those who underwent open surgery for aortic arch aneurysms without dissection. However, in the aforementioned study, no difference was reported between the groups in terms of the weaning period. In other studies, no difference was reported between two methods in terms of ICU stay or weaning period; this did not support the hypothesis that the hybrid procedure would show improvements in these variables owing to its less invasive nature. ${ }^{[12,13,15]}$ Interestingly, in a study by Tokuda et al. ${ }^{[15]}$ including 192 patients, open surgery had better results in terms of these same variables, and no difference during the perioperative period was reported between two techniques. Only a few studies reported that the hybrid procedure was superior to open surgery in terms of the 
need for re-surgery and blood transfusion. ${ }^{[13]}$ In our study, we found that the hybrid procedure was superior to open surgery in terms of the amount of drainage, reoperation due to bleeding, and weaning period. However, we found no significant difference in the need for blood transfusion, duration of ICU stay, or early postoperative complications between the two groups.

Although data are available on the mid-to-long-term results of open surgery and endovascular methods for abdominal and descending aortic aneurysms, such data on the hybrid procedure and open surgery performed for aortic arch aneurysms have only recently been reported, since the hybrid procedure is a relatively new method. In one of the earliest reports, Milewski et al. ${ }^{[12]}$ reported no difference between the two techniques in terms of early and late mortality rates. In the aforementioned study, there was a difference in the mortality rate between patients above the age of 75 versus those under the age of 75 in the open surgery group. In the study by De Rango et al., ${ }^{[17]}$ a hybrid procedure was used in older patients and those with several comorbidities, and no difference was found between open surgery and the hybrid procedure in terms of perioperative death and four-year survival rates. In the study of Cazavet et al. ${ }^{[18]}$ including 46 patients, open surgery and hybrid procedure were compared in patients with aortic arch aneurysms, and no difference between the two techniques was found in terms of the one, three, five, and seven-year survival rates. However, the authors reported that open surgery was superior to the hybrid procedure in terms of the re-intervention rates. Kang et al., ${ }^{[14]}$ Tokuda et al., ${ }^{[15]}$ and Iba et al. ${ }^{[16]}$ also reported similar results in their studies. In four studies and a meta-analysis including 378 patients, there was no difference between the two methods in terms of early and late mortality rates; however, the rate of events causing permanent neurological damage was lower in the open surgery compared to the hybrid procedure group.$^{[19]}$ Regarding all of these studies, it should be kept in mind that the hybrid procedure was used mainly in older patients and in those with several comorbidities and, thus, high EuroSCOREs. Accordingly, even if there is a situation related to survival favoring the use of a hybrid procedure, this may be eliminated due to the group of higher-risk patients. In our study, we found that the two techniques were similar in terms of the incidence of MACEs, survival rates, and the need for reoperation; given that both groups were homogeneous in terms of comorbidities, we believe that this is a valuable finding.

To identify the zone where the endovascular graft should be placed during the hybrid procedure, standard proximal landing zone classifications were used. ${ }^{[3]}$ Accordingly, there are differences in aortic arch reconstruction, depending on the proximal landing zone. The incidence of temporary or permanent neurologic damage is usually higher than those of conventional TEVAR practices in hybrid procedures, while this rate varies from 0 to $20 \%$ among studies (in the case of Zone 1 and Zone 2 settlement in particular). ${ }^{[1,20,21]}$ Neurological damage is higher in these cases due to emerging embolism with higher degrees of aortic arch debranching, which are used for guidewire and endograft manipulations. ${ }^{[22]}$

As the proximal parts of the brachiocephalic arteries were ligated in patients undergoing total arch debranching with graft placement in Zone 0 , there was a mild risk during the endovascular procedure. ${ }^{[1]}$ Another benefit of using Zone 0 as the proximal landing zone is that the risk of type $1 \mathrm{~A}$ endoleak, particularly that seen in Zone 1, is reduced according to several studies. ${ }^{[23,24]}$ In our study, Zone 0 was used in all patients, and neither an early neurological event nor a type $1 \mathrm{~A}$ endoleak was observed in any of the patients.

In the present study, we performed all hybrid practices in the operating room at a single session. Performing the hybrid procedures during the same session eliminated drawbacks, such as a long operation period, higher volumes of blood loss, and the need for contrast agents. ${ }^{[20,22]}$ Furthermore, we believe that performing the procedure in a single session of anesthesia has a psychologically protective effect on the patient; it also allows us to perform surgical intervention for any complication that may occur during the endovascular procedure.

The limitations of our study included its small sample size and retrospective design. However, as mentioned above, our study is different from others, as all the patients included had aneurysms; furthermore, the patients in both groups were similar to each other in terms of all preoperative variables, particularly the EuroSCOREs.

In conclusion, the short-term and long-term results of conventional open surgery and the hybrid procedure for aortic arch aneurysms are rather promising and both methods can be performed feasibly by reliable and experienced teams. However, there is a need for at least 10-year follow-up results to compare these two methods more precisely.

\section{Declaration of conflicting interests}

The authors declared no conflicts of interest with respect to the authorship and/or publication of this article. 


\section{Funding}

The authors received no financial support for the research and/or authorship of this article.

\section{REFERENCES}

1. Yilik L, Gokalp O, Yurekli I, Bayrak S, Gunes T, Karakas N, et al. Hybrid repair of aortic arch aneurysms in same session. Thorac Cardiovasc Surg 2012;60:501-7.

2. Yilik L, Gunes T, Ozsoyler I, Gurbuz A. Hybrid approaches to repair of aortic pathologies. Turkiye Klinikleri J Cardiovasc Surg-Special Topics 2009;2:64-75.

3. Szeto WY, Bavaria JE. Hybrid repair of aortic arch aneurysms: combined open arch reconstruction and endovascular repair. Semin Thorac Cardiovasc Surg 2009;21:347-54.

4. Antoniou GA, Mireskandari M, Bicknell CD, Cheshire NJ, Gibbs RG, Hamady M, et al. Hybrid repair of the aortic arch in patients with extensive aortic disease. Eur J Vasc Endovasc Surg 2010;40:715-21.

5. Sundt TM, Orszulak TA, Cook DJ, Schaff HV. Improving results of open arch replacement. Ann Thorac Surg 2008;8:787-96.

6. Gurbuz A, Yilik L, Gokalp O. Hybrid tevar interventions. Turkiye Klinikleri J Cardiovasc Surg-Special Topics 2012;4:58-67.

7. Ozen A, Altıntas G, Kervan U, Unal EU, Yilmaz M, Ozen S, et al. Factors affecting long-term survival of patients undergoing aortic surgery using the antegrade selective cerebral perfusion technique. Turk Gogus Kalp Dama 2014;22:13-8.

8. Hastaoglu IO, Tokoz H, Bilginer N, Bilgen F. Mid-term results of endovascular stent grafting: where do we stand on desired mortality in high-risk patients. Turk Gogus Kalp Dama 2014;22:558-63.

9. Boehme AK, Hays AN, Kicielinski KP, Arora K, Kapoor N, Lyerly MJ, et al. Systemic Inflammatory Response Syndrome and Outcomes in Intracerebral Hemorrhage. Neurocrit Care 2016;25:133-40.

10. Strauch JT, Spielvogel D, Lauten A, Galla JD, Lansman SL, McMurtry K, et al. Technical advances in total arch replacement. Ann Thorac Surg 2004;77:581-90.

11. Neri E, Massetti M, Sani G. The "elephant trunk" technique made easier. Ann Thorac Surg 2004;78:17-8.

12. Milewski RK, Szeto WY, Pochettino A, Moser GW, Moeller P, Bavaria JE. Have hybrid procedures replaced open aortic arch reconstruction in high-risk patients? A comparative study of elective open arch debranching with endovascular stent graft placement and conventional elective open total and distal aortic arch reconstruction. J Thorac Cardiovasc Surg 2010;140:590-7.
13. Preventza O, Garcia A, Cooley DA, Haywood-Watson RJ, Simpson K, Bakaeen FG, et al. Total aortic arch replacement: A comparative study of zone 0 hybrid arch exclusion versus traditional open repair. J Thorac Cardiovasc Surg 2015;150:1591-8.

14. Kang WC, Ko YG, Shin EK, Park CH, Choi D, Youn YN, et al. Comparison of hybrid endovascular and open surgical repair for proximal aortic arch diseases. Int $\mathrm{J}$ Cardiol 2016;203:975-9.

15. Tokuda Y, Oshima H, Narita Y, Abe T, Araki Y, Mutsuga $\mathrm{M}$, et al. Hybrid versus open repair of aortic arch aneurysms: comparison of postoperative and mid-term outcomes with a propensity score-matching analysis. Eur J Cardiothorac Surg 2016;49:149-56.

16. Iba Y, Minatoya K, Matsuda H, Sasaki H, Tanaka H, Oda $\mathrm{T}$, et al. How should aortic arch aneurysms be treated in the endovascular aortic repair era? A risk-adjusted comparison between open and hybrid arch repair using propensity scorematching analysis. Eur J Cardiothorac Surg 2014;46:32-9.

17. De Rango P, Ferrer C, Coscarella C, Musumeci F, Verzini F, Pogany G, et al. Contemporary comparison of aortic arch repair by endovascular and open surgical reconstructions. J Vasc Surg 2015;61:339-46.

18. Cazavet A, Alacoque X, Marcheix B, Chaufour X, Rousseau $\mathrm{H}$, Glock Y, et al. Aortic arch aneurysm: short- and mid-term results comparing open arch surgery and the hybrid procedure. Eur J Cardiothorac Surg 2016;49:134-40.

19. Benedetto U, Melina G, Angeloni E, Codispoti M, Sinatra R. Current results of open total arch replacement versus hybrid thoracic endovascular aortic repair for aortic arch aneurysm: a meta-analysis of comparative studies. $\mathrm{J}$ Thorac Cardiovasc Surg 2013;145:305-6.

20. Chan YC, Cheng SW, Ting AC, Ho P. Supra-aortic hybrid endovascular procedures for complex thoracic aortic disease: single center early to midterm results. J Vasc Surg 2008;48:571-9.

21. Schumacher H, Von Tengg-Kobligk H, Ostovic M, Henninger $\mathrm{V}$, Ockert S, Böckler D, et al. Hybrid aortic procedures for endoluminal arch replacement in thoracic aneurysms and type B dissections. J Cardiovasc Surg (Torino) 2006;47:509-17.

22. Riesenman PJ, Tamaddon HS, Farber MA. Surgical bypass procedures to facilitate endovascular repair of aortic arch pathology. J Cardiovasc Surg (Torino) 2008;49:461-9.

23. Melissano G, Civilini E, Bertoglio L, Calliari F, Setacci F, Calori G, et al. Results of endografting of the aortic arch in different landing zones. Eur J Vasc Endovasc Surg 2007;33:561-6.

24. Tse LW, MacKenzie KS, Montreuil B, Obrand DI, Steinmetz OK. The proximal landing zone in endovascular repair of the thoracic aorta. Ann Vasc Surg 2004;18:178-85. 